\title{
Unique lentivirus infecting feral simians from forests of Rajasthan, India
}

\author{
Jayashree S Nandi ${ }^{1,2^{*}}$, Anil K Chhangani ${ }^{3}$, Surendra M Mohnot ${ }^{4}$, Felipe Diaz-Griffero ${ }^{1}$ \\ From 15th International Conference on Human Retroviruses: HTLV and Related Viruses \\ Leuven and Gembloux, Belgium. 5-8 June 2011
}

Lentivirus infection of wild rhesus macaques (Macaca mulatta) and langurs (Semnopithecus entellus) from forests of Rajasthan was suspected based on testing of simian plasma samples by commercial HIV-1 WB in 1998. Though simians have a religious connotation in India, aggressive monkey bites are frequently reported from urban and rural areas due to habitat fragmentation of wild simians. Blood samples from 34 feral rhesus macaques and 9 langurs were collected recently from forests of Rajasthan. Plasma samples were tested using monoclonal antibody against capsid proteins of SIVmac (p27) and HIV-1 (p24). Mitochondrial gene analyses confirmed the species of origin. Integrated provirus was detected by AluLTR amplification. Lentiviral genes, gag, pol, env, nef, vif, vpr and LTR were amplified and sequenced. Viral load assay was performed independently. Virus purified from simian plasma by ultracentrifugation was used to infect human PBMC, H9 (CD4+, CXCR4+) and U87 (CD4+, $\mathrm{CCR} 5+)$ cell lines. Virus replication in vitro was detected by p 24 antigen capture ELISA and microscopic syncytia formation. Phylogenetic analyses of viral sequences demonstrated intriguing homology to subtype B HIV-1 rather than any known SIV. Significant sequence divergence from HXB2 existed in different regions of viral genome except for conserved pol (RT) region, ruling out inadvertent laboratory contamination. Serological activity was observed against HIV-1 p24 but not SIVmac p27. Reverse transmission of subtype B HIV-1, which is transmitted in north India from infected humans to feral simians due to bleeding monkey bite followed by horizontal spread of the infection in troops of wild simians is proposed.

\footnotetext{
* Correspondence: jseemanandi@gmail.com

'Dept. of Microbiology and Immunology, Albert Einstein College of Medicine, NY, 10461, USA

Full list of author information is available at the end of the article
}

\section{Author details}

${ }^{1}$ Dept. of Microbiology and Immunology, Albert Einstein College of Medicine, NY, 10461, USA. ²Dept. of Microbiology and Cell Biology, Indian Institute of Science, Bangalore, 560012, India. ${ }^{3}$ Dept. of Zoology, JNV University, Jodhpur, Rajasthan, India. ${ }^{4}$ Primate Research Centre, Jodhpur, Rajasthan, India.

Published: 6 June 2011

doi:10.1186/1742-4690-8-S1-A212

Cite this article as: Nandi et al:: Unique lentivirus infecting feral simians from forests of Rajasthan, India. Retrovirology 2011 8(Suppl 1):A212.
Submit your next manuscript to BioMed Central and take full advantage of:

- Convenient online submission

- Thorough peer review

- No space constraints or color figure charges

- Immediate publication on acceptance

- Inclusion in PubMed, CAS, Scopus and Google Scholar

- Research which is freely available for redistribution

\section{() Biomed Central}

C Biomed Central

ㄷ 2011 Nandi et al; licensee BioMed Central Ltd. This is an open access article distributed under the terms of the Creative Commons Attribution License (http://creativecommons.org/licenses/by/2.0), which permits unrestricted use, distribution, and reproduction in any medium, provided the original work is properly cited. 